\title{
Pollution of Heavy Metal Threat Posed by E-waste Burning and Its Assessment of Human Health Risk
}

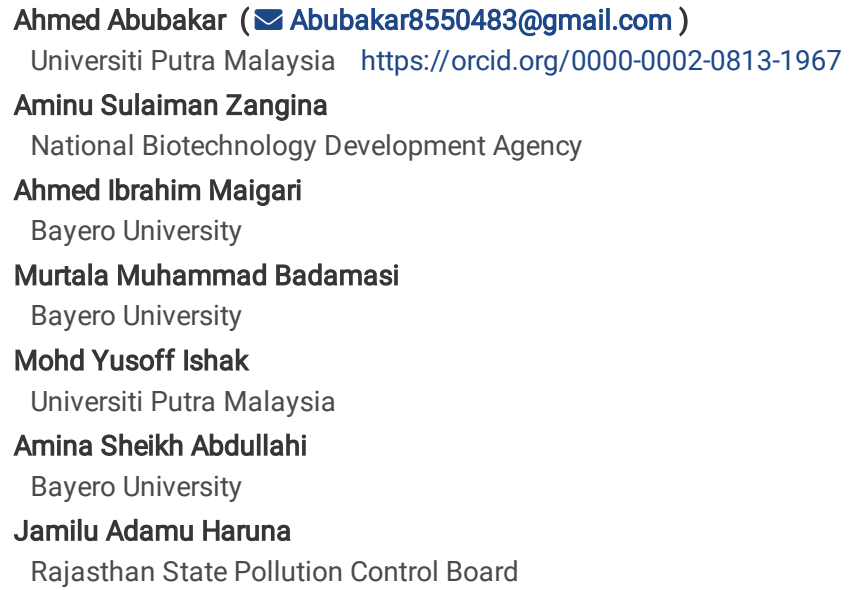

Version of Record: A version of this preprint was published at Environmental Science and Pollution Research on April 18th, 2022. See the published version at https://doi.org/10.1007/s11356-022-19974-6. 


\section{Abstract}

Improper treatment during recycling of e-waste materials by means of open burning is on the rise which has led to increase in air pollution. This study looked at heavy metal concentrations, concentration in relation to threshold values and assessment of risk for non-carcinogenic and cancer risk threat. MP-AES 4210 series instrument of Agilent technology, USA was used in analyzing the heavy metals $(\mathrm{Cd}, \mathrm{Cu}$, and $\mathrm{Pb})$ concentration. The result of the analysis at Kuka Bulukiya treatment point revealed $\mathrm{Pb}$ has the highest mean concentration of $0.0693 \mathrm{ppm}, \mathrm{Cu} 0.0525 \mathrm{ppm}$ and Cd having $0.0042 \mathrm{ppm}$. The mean concentration at PRP G/Ruwa for Cd was found to be $0.0059 \mathrm{ppm}$, Cu was $0.0363 \mathrm{ppm}$ and Pb was 0.049 ppm respectively. The result of the adult and children population calculated shows that the $\mathrm{HQ}$ and $\mathrm{HI}$ values are not up to 1 in all the pathways (inhalation, ingestion, and dermal) at both treatment points $\left(1.2 \otimes 10^{-4}\right.$ and $\left.9.8 \otimes 10^{-5}\right)$ and $\left(6.4 \otimes 10^{-4}\right.$ and $\left.5.9 \otimes 10^{-4}\right)$ respectively. The cancer risk for Kuka Bulukiya $6 \otimes 10^{-10}$ and PRP G/Ruwa $5 \otimes 10^{-10}$ for adults and $7 \otimes 10^{-}$ 10 and $4 \otimes 10^{-10}$ for children were both lower than the threshold set for cancer risk by United States Environmental Protection Agency. This meant that both adults and children were not at risk of cancer and non-carcinogenic threat based on the assessment in this study. The study concluded that informal e-waste burning has substantially helped in the relatively high levels of air pollution identified in the treatment points and in turn posed environmental and public health concerns to people around the area. Climate change adaptation has to do with an environmentally friendly method of dismantling, extracting, refurbishing and recycling of valuable materials that should be at the forefront of policies that will be specifically enacted on e-waste management in developing countries. If not the adverse effects on the environment, humans (damage reproductive, nervous system, kidney, liver, heart and also lead to birth defects and diseases) and animals will be enormous. Government should identify a suitable location for e-waste collection and treatment points to avert the danger posed to the agricultural practices at PRP G/Ruwa treatment point and the pond at Kuka Bulukiya treatment point. Samples of the vegetable products at PRP G/Ruwa treatment point should be investigated immediately and adequate restrictions and regulations should be enacted and enforced in order to safeguard the environment and the populace. There is need for caution from the authorities to avert the possible implications (e-waste extractors and the public) of being affected with non-carcinogenic or carcinogenic ailments over time.

\section{Introduction}

Electrical electronic equipment (EEE) that has reached the unwanted stage known to be e-waste is about the fastest rising waste streams globally (Tsydenova and Bengtsson 2011; Ikhlayel 2018). E-waste is considered hazardous substances because of the composition of heavy metals, flame retardants, and other substances (Tsydenova and Bengtsson 2011). Studies have identified sites where e-waste is recycled and its surrounding to be the key source of numerous escaped pollutants (Chen et al. 2018; Shen et al. 2019) and the concentration of related pollutants is more in urban areas (Huang et al. 2013). However, in spite of the potential toxicity of pollutants that's becoming obvious data on their environmental happening and exposure to human still remains mainly unfamiliar (Li et al. 2020).

As of now the informal recycling centers has dominated the e-waste industry and treating 90 to 95 percent of generated e-waste in an unfriendly manner in developing countries (Vats and Singh 2014). However, the informal sectors doesn't follow the set guidelines by authorities but uses crude method of disposal such as open burning in order to recover valuable resources such as gold, silver, palladium, iron, plastics, etc and releases toxic metals such as lead, arsenic, cadmium, chromium, mercury at the treatment sites (Vats and Singh 2014) causing undue public and environmental health concerns. E-waste burning in an open place releases dioxins and polycyclic aromatic compounds which are grossly more toxic than burning of domestic waste (Dave et al. 2016). However, only 78 countries are covered globally by e-waste policy, legislation or regulation (Forti et al. 2020) this is part of the challenges faced in terms of its generation, collection and disposal.

Public and environmental healths are thing of concern due to the fast growing of e-waste materials and the intricate composition and unsafe nature of metals contain in them (Dave et al. 2016). As of 2019 about 53.6 million metric tonnes of e-waste was generated and it was estimated to go beyond 74 Mt by 2030 (Forti et al. 2020). This implies that e-waste is increasing at a disturbing rate and the potential danger posed is quite enormous. It is an alarming threat to the extractors that dismantle the e-waste to get valuable metals (Dave et al. 2016) and the people living closer to the dismantling, recycling and treatment points. The workers and people around e-waste recycling areas are uninformed of the harmful nature of the materials and the action of the extractors as they are not using protective equipments (Li et al. 2008).

Lead and cadmium in glass panels, gaskets, circuit boards, chip resistors, semi conductors result to damage in kidney, adverse effect on children brain development and copper in copper wires and PCBs results in nausea, liver damage, Wilson's disease, or stomach cramps (Monica and Jugal Kishore 2010; Padiyar 2011). However, bare hands dismantling and separation of components of e-waste cannot be unconnected with skin and other respiratory diseases. It was asserted that major route of e-waste contaminants is through air by means of inhalation, ingestion, and dermal absorption (Priyadarshini 2011). However, addressing the pressing threat e-waste posed to the extractors and the people living around the treatment points prompt to undertaking this study. This will add to the pool of knowledge of enormous hazardous nature of burning of e-waste in open place and the respective public health concern.

It is asserted that burning of e-waste in open place releases various metal(loids) into the environment which has call for concern globally (Cao et al. 2020). For extraction of valuable resources e-waste materials are burnt at the two treatment points identified in the study area (Kuka Bulukiya and PRP Gidan Ruwa). In other words, the study of Gangwar et al. (2019) has indicated that the recycling of e-waste presented a tremendous threat the populace and the environment. Luo et al. (2011) has highlighted that metal concentration at soils of e-waste burning sites, is highest in relation to the surrounding areas in China. However, these studies and others prompt the need to explore the potential health risk exposed to by the extractors and the public around the treatment points in this study.

This method of calculating the threat associated with taking in air from burning of e-waste materials was recommended by USEPA. The idea behind it all is to see the potential risk the extractors and the public around the treatment points are exposed to. So, this method best suites that idea. It is better than other methods in the sense that it best suites determining the aim of the study. Other methods used were aimed at determining whether the people around the 
treatment area have develop non-carcinogenic ailments or carcinogenic risk due to taken in contaminated air from e-waste activities by taking blood or urine samples of the extractors or the resident around the treatment points. This requires studying the people under study over a long period of time to making sure other factors or substances did not play a role in determining the outcome of the study and this is not the interest of this study as such it adopts the method used in this study. This is a novel research in the study area as nothing on e-waste activities has been investigated or determined. What is interesting is the ability of undertaking the research and identifying the treatment points. It has been established by the results that the concentration of heavy metals at the treatment points is way higher than the samples away (control) from the points. It has also been asserted that the results of some of the samples were higher than the results in other studies and in set threshold values by authorities. Another interesting thing is that the results of samples from Kuka Bulukiya is higher than the results from PRP G/Ruwa due to the frequency of activities at Kuka Bulukiya and this corroborate the actual situation on the ground.

Notwithstanding, the concentration and other factors (physiological and anatomical conditions of adults and children) combined used in the calculation revealed that there is no non-carcinogenic and carcinogenic threat posed by their activities as of now. This implies that the public around the treatment points and the extractors are safe for now which is very much interesting. But, the results also revealed the need for caution in their activities in order to safeguard the environment and the populace.

Identifying e-waste activities and the treatment points where the contamination of the surrounding environment especially air is taking place. The study revealed that there is hazard identification in the study area or any area globally with similar activities. Exposure assessment and toxicity (dose response) assessment were revealed based on the concentration. Risk characterization of the assessments was undertaken and this help revealed the potential danger of being infected with non-carcinogenic or carcinogenic ailments. What this has added to the pool of literature is that depending on the concentration of the contaminants and other factors one cannot vividly say you are going to be infected with certain ailments (carcinogenic and non-carcinogenic) without subjecting a phenomenon to some measurements or test.

Notwithstanding, this study looked at heavy metal concentration in the air at the treatment points and in order to identifying the hazard. The concentration was measured in relation to the set threshold by National Environmental Standards and Regulations Enforcement Agency (NESREA), United States Environmental Protection Agency and National Ambient Air Quality Standards (NAAQS). Assessment of risk for non-carcinogenic and carcinogenic threat through pathways such as inhalation, ingestion, and dermal contact was undertaken in this study (at the two treatment points identified). This highlighted the danger of unsound e-waste burning practices and its toxicity in cities of developing countries.

Review of related studies

Depending on the type of electrical and electronic equipment there is wide range of precious metals and other base metals contained in those devices (Ghosh et al. 2015; Cucchiella et al. 2015). On the other aspect of the components there are toxic substances contained in electrical and electronic devices which are harmful to the environment and human as well. Improper disposal or unsound management of e-waste leads to undesirable contamination of the environment and severe health related challenges (Cesaro et al. 2019). In a real sense, WEEE need to be collected, sorted, extracted, treated, transported and disposed properly with environmental and human safety as the main goal.

However, the informal WEEE recycling points are usually done in an unsound and crude conditions at backyard of urban environment or at in informal collection points with the central goal of extracting precious metals such as gold and silver (Ceballos and Dong 2016) especially in developing countries. The e-waste are usually dismantled and separated manually to acquire its valuable components and sometimes the WEEE is subjected to treatments before extracting the valuable components. Usually, these treatments are mostly acid treatment and open burning (Cesaro et al. 2019). Since sound environmental conditions are not followed, there is likelihood of severe potential health risks to the extractors and the public living around the treatment points. Nevertheless, recent studies (Table 1) have revealed the contamination of air, water and soil from e-waste related activities (Tue et al. 2016) various concentrations of heavy metal and other toxic substances have been detected within the informal treatment points and the surrounding area (Awasthi et al. 2016). This scenario has posed risks to human health, that is to both those that engaged in e-waste activities and to those residing close to the treatment points vicinity, the mixture of e-waste toxic substances and other environmental contaminants and lead to a more severe health and environmental hazards (Bakhiyi et al. 2018).

Treatment of WEEE through open burning

The open burning of e-waste to recover copper from cable wires and other component from different devices is apparent (Cesaro et al. 2019). This is often done on bare surfaces and at relatively low temperatures and this is identified as the most reported crude method of recycling e-waste (Perkins et al. 2014). Open burning of e-waste has a direct implication on the environment by releasing toxic substances into the atmosphere, contaminating the soil on which it was burnt, and polluting the nearby water bodies through run off (Alcantara-Concepcion et al. 2016). This implies that the effects on human health either come by directly during processing and treatment or indirectly through taking contaminated water or through the food chain. Imran et al. (2017) has revealed that air is the most significant medium of transportation of contaminants during open burning and has asserted that both the workers and people around the area are having trouble in breathing. Such situations has exposed the environmental concerns there in considering the number of hours spent at the treatment or recycling points and how frequent one visits. Table 1 showed the review of related studies. 
Table 1

Review of related studies

\begin{tabular}{|c|c|c|}
\hline $\begin{array}{l}\text { Author and } \\
\text { Year }\end{array}$ & Title of the article & Main Findings \\
\hline $\begin{array}{l}\text { Bungadaeng } \\
\text { et al. (2019) }\end{array}$ & $\begin{array}{l}\text { Inhalation exposure to respirable } \\
\text { particulate matter among workers in } \\
\text { relation to their e-waste open burning } \\
\text { activities in Buriram Province, } \\
\text { Thailand }\end{array}$ & $\begin{array}{l}\text { The average } \mathrm{PM}_{2.5} \text { mass concentrations accounted for } 75 \pm 18 \% \text { from those of } \mathrm{PM}_{10} \text {, suggesting } \\
\text { that } \mathrm{PM}_{2.5} \text { was the main component of particulate matter that the workers were exposed to } \\
\text { during the burning activity. The study also found that increased amounts of burnt e-waste } \\
\text { significantly influenced the concentrations of coarse and fine particles emitted. }\end{array}$ \\
\hline $\begin{array}{l}\text { Cao et al. } \\
(2020)\end{array}$ & $\begin{array}{l}\text { Bioaccessibility and human health } \\
\text { risk assessment of metal(loid)s in } \\
\text { soil from an e-waste open burning } \\
\text { site in Agbogbloshie, Accra, Ghana }\end{array}$ & $\begin{array}{l}\text { In human health risk assessments (HHRAs), oral ingestion of soil can be a major route of } \\
\text { exposure to many immobile soil contaminants. The hazard index was above the threshold value } \\
(>1) \text { for } 5 / 10 \text { samples, indicating a potential health risk to local inhabitants. }\end{array}$ \\
\hline $\begin{array}{l}\text { Cesaro et al. } \\
(2019)\end{array}$ & $\begin{array}{l}\text { A relative risk assessment of the } \\
\text { open burning of WEEE }\end{array}$ & $\begin{array}{l}\text { The results provided for the first time a comparative analysis of the risk posed from the open } \\
\text { burning of WEEE components, proposing a methodology to address the absolute risk assessment } \\
\text { to workers from the informal recycling of WEEE. }\end{array}$ \\
\hline $\begin{array}{l}\text { Kumar and } \\
\text { Prakash } \\
\text { (2019) }\end{array}$ & $\begin{array}{l}\text { Risk Assessment Environmental } \\
\text { Impact of E-Waste Management }\end{array}$ & $\begin{array}{l}\text { Potential environmental health consequences of these toxic metals and organo compounds are } \\
\text { described. }\end{array}$ \\
\hline $\begin{array}{l}\text { Liu et al. } \\
(2021)\end{array}$ & $\begin{array}{l}\text { Heavy metals in soil-vegetable } \\
\text { system around E-waste site and the } \\
\text { health risk assessment }\end{array}$ & Results indicated that both adults and children were suffering potential health risks. \\
\hline $\begin{array}{l}\text { Mowla et al. } \\
(2019)\end{array}$ & $\begin{array}{l}\text { Health risk assessment of heavy } \\
\text { metals in E-waste recycling shops in } \\
\text { Dhaka, Bangladesh }\end{array}$ & $\begin{array}{l}\text { The amount of hazardous material in the dust samples surrounding these areas was } \\
\text { determined and the potential health risk was found using some empirical co-relations. }\end{array}$ \\
\hline $\begin{array}{l}\text { Ngo et al. } \\
(2021)\end{array}$ & $\begin{array}{l}\text { Environmental Health Risk } \\
\text { Assessment of Heavy Metal } \\
\text { Exposure among Children Living in } \\
\text { an Informal E-waste Processing } \\
\text { Village } \\
\text { in Vietnam }\end{array}$ & $\begin{array}{l}\text { The findings revealed that levels of the total average daily intake (ADI) of the five heavy metals } \\
\text { collected from a child at the exposed village were } 3.90 \text { times higher than that of a child at the } \\
\text { reference village. The total non-carcinogenic risk and } \\
\text { carcinogenic risk in an exposed child were } 1.63 \text { and } 4.70 \text { folds higher than their respective risks in } \\
\text { a reference child. }\end{array}$ \\
\hline $\begin{array}{l}\text { Oguri et al. } \\
(2017)\end{array}$ & $\begin{array}{l}\text { Exposure assessment of heavy } \\
\text { metals in an e-waste processing area } \\
\text { in northern Vietnam }\end{array}$ & $\begin{array}{l}\text { Garden soil and floor dust were estimated to be mainly contributors to daily Pb intake, as } \\
\text { indicated by calculations using bioaccessible metal concentrations and the U.S. Environmental } \\
\text { Protection Agency soil plus dust ingestion rate. }\end{array}$ \\
\hline $\begin{array}{l}\text { Singh et al. } \\
(2018)\end{array}$ & $\begin{array}{l}\text { Health risk assessment of the } \\
\text { workers exposed to the heavy metals } \\
\text { in e-waste recycling sites of } \\
\text { Chandigarh and Ludhiana, Punjab, } \\
\text { India }\end{array}$ & $\begin{array}{l}\text { High concentration of } \mathrm{Ba}, \mathrm{Cu}, \mathrm{Pb} \\
13 \text { and } \mathrm{Zn} \text { was observed in the soil and dust samples. } \mathrm{Cr}, \mathrm{Pb} \text { and } \mathrm{Zn} \text { were observed in high } 14 \\
\text { concentrations in dermal samples. }\end{array}$ \\
\hline $\begin{array}{l}\text { Zhang et al. } \\
(2019)\end{array}$ & $\begin{array}{l}\text { Heavy metals in human urine, foods } \\
\text { and drinking water from an e-waste } \\
\text { dismantling area: Identification of } \\
\text { exposure sources and metal-induced } \\
\text { health risk }\end{array}$ & $\begin{array}{l}\text { Risk assessment predicted that dust ingestion of } \mathrm{Cd}, \mathrm{Pb}, \mathrm{Cu} \text {, and } \mathrm{Zn} \text { via food consumption poses } \\
\text { health risks to local residents of ED As, and the urinary concentrations of analyzed metals were } \\
\text { significantly (Pearson correlation coefficient: } r=0.324-0.710 ; \mathrm{p}<0.01 \text { ) associated with elevated } \\
8-\mathrm{OHdG} \text {, a biomarker of oxidative stress in humans. }\end{array}$ \\
\hline
\end{tabular}

Background on the study area

Location

The treatment points are found within Kano metropolis on latitude 12.00782 and longitude 8.50407 (Dala Kuka Bulukiya) and latitude 12.0388697 and longitude 8.5409142 (PRP Gidan Ruwa, Brigade) respectively in the Sudan Savanna region of Nigeria. It is about the most evident e-waste treatment points in the region where e-waste open burning takes place in order to get the valuable resources in them. There is large population of people surrounding the treatment points as it is found within the vicinity of cities in developing countries.

Climate

The study area is known for its four distinct seasons. The dry and cool known as Kaka (Winter period), the dry and hot known as Bazara (Spring period), the wet and warm referred to as Damuna (Summer period), and the dry and warm season known as Rani (Fall or Autumn period).

\section{Materials And Methods}

\section{Nature and sources of data}

Quantitative data type was from the laboratory analysis conducted. The air data was collected at the treatment points where open burning of e-waste is usually done. 
Two treatment points were chosen and they were identified as the hotspots in Kano metropolis. The air was captured at 3 different times $\left(28^{\text {th }}\right.$ December, $2020,11^{\text {th }}$ and $18^{\text {th }}$ January, 2021) at different intervals $(0 \mathrm{~m}, 5 \mathrm{~m}$ and $10 \mathrm{~m})$ in the treatment points (each of the site) during the day. 9 samples were collected (for each treatment points) and homogenized into 3, that is 3 times for each interval. The SKC air sampling sidekick pump with flow range of 5-3000 ml/min developed by SKC Ltd, UK was used to collect the heavy metals in the particulate matter from the treatment points on the filter paper inserted (Kim et al. 2010). The Gelman Sciences (Ann Arbor, Michigan, USA) filter was inserted on the pump and the air was collected in order to capture the heavy metals. The filters were stored in desiccators until the mass become constant and weighed in a $0.1 \mathrm{mg}$ unit scale, they were dried, weighed and kept in the desiccators for analytical purpose. The control was collected about a $100 \mathrm{~m}$ away from the treatment points.

Air preparation and analysis: In the analysis of the captured metals, the filter was pretreated with a hot plate. The USEPA method of digestion was adopted (USEPA 2016a lab manual revised). The filters were put in a conical flask to which $98 \%$ stock solution nitric acid $5 \mathrm{ml}$ and deionized water of $5 \mathrm{ml}$ were added. Thereafter, the opening was closed; the samples were decomposed with the hot plate digestion system. However, in the decomposition process the temperature was at $170^{\circ} \mathrm{C}$ for 15 minutes during the first step. Hydrogen peroxide $75 \%$ solution was added to neutralize the acid; $100 \mathrm{ml}$ of deionized water was used to dilute the solution and was put back onto the hot plate until the yellow fumes stops for the second step. In the third step, the solution was taken down and allows to cool to room temperature for about120 minutes. Microwave Plasma-Atomic Emission Spectrometer (MP-AES 4210 series) instrument of Agilent technology, USA was used for the concentration of heavy metals $(\mathrm{Cd}, \mathrm{Cu}$, and $\mathrm{Pb})$ analysis.

\section{Exposure Assessment}

The study assessed the health risk threat to certain heavy metals like $\mathrm{Cd}, \mathrm{Cu}$, and $\mathrm{Pb}$ in e-waste treatment points through burning that might lead to noncarcinogenic and carcinogenic ailments. The exposure assessment calculated the average daily intake (ADI) and the lifetime average daily dose (LADD) of metals identified all the way through inhalation, ingestion, and dermal pathways by adults and children in the two treatment points. The non-carcinogenic threshold that is RfD (reference dose) and the CSF (cancer slope factor) (which is a potential carcinogen factor) are two substantial toxicity index used in this study. The equations used in this study were recommended by USEPA (1989).

Inhalation of Heavy Metals

$A D I_{\text {inh }}=C \otimes I R a i r \otimes E F \otimes E D \otimes E T / B W \otimes A T \otimes P E F \ldots \ldots . .[1]$

$A D I_{\text {inh }}$ is the average daily intake of heavy metals inhaled, that is the quantity of contaminants ( $\mathrm{mg} / \mathrm{kg}$.day); and for evaluating carcinogenic impurities it is referred to as lifetime average daily dose, LADD, while for noncarcinogenic contaminants is known as average daily dose, $A D D$ or $A D I$; $C$ is the concentration in the media of interest $\left(\mathrm{mg} \mathrm{kg}^{-1}\right), \mathrm{IR}_{\text {air }}$ is the rate of inhalation $\left(\mathrm{m}^{3}\right.$ day $\left.{ }^{-1}\right), \mathrm{EF}$ is the frequency of exposure (days year $\left.{ }^{-1}\right)$, ED is the duration of exposure (years), BW is weight of the body $(\mathrm{kg}), \mathrm{PEF}$ is the particulate emission factor in $\mathrm{m}^{3} / \mathrm{kg}$, ET is the time of exposure in hr/day, AT is average time equals 25550 days based on a life time of 70 years for cancer risk; and for noncarcinogens, averaging equals ED (years) multiplied by 365 days per year.

Ingestion of Heavy Metals

$A D I_{\text {ing }}=C \otimes I R \otimes E F \otimes E D \otimes C F / B W \otimes A T$...... [2]

$A D l_{\text {ing }}$ is the average of daily intake of the heavy metals ingested, that is the amount of contaminants (mg/kg.day); C is the concentration in the media of concern $\left(\mathrm{mg} \mathrm{kg}^{-1}\right), \mathrm{IR}$ is the ingestion in $\mathrm{mg} /$ day, EF is the frequency of exposure (days year ${ }^{-1}$ ), duration of exposure is ED (years), BW is the weight of the body $(\mathrm{kg})$, AT is the average time period in days, and CF is the factor of conversion in $\mathrm{kg} / \mathrm{mg}$.

Dermal Contact

$A D I_{\text {derm }}=C \otimes E F \otimes A F \otimes E D \otimes S A \otimes A B S \otimes C F / B W \otimes A T \ldots \ldots . .[3]$

$A D I_{\text {derm }}$ is the dermal contact exposure ( $\mathrm{mg} / \mathrm{kg}$.day); $\mathrm{C}$ is the concentration in the media of concern $\left(\mathrm{mg} \mathrm{kg}^{-1}\right), A F$ is the soil adherence factor in $\mathrm{mg} / \mathrm{cm}^{2}, \mathrm{SA}$ is exposed skin area in $\mathrm{cm}^{2}, \mathrm{ABS}$ is the fraction of the applied dose absorbed on the skin, BW, ED, AT, EF and CF as defined in equation (2)

\subsubsection{Noncarcinogenic Risk Assessment}

Noncarcinogenic threats are known as hazard quotient (HQ). This is expressed as a unitless value that shows the possibility of someone developing an adverse health effect. This is defined as the quotient of ADI divided by the toxicity threshold value (RfD), which is the persistent reference dose in mg/kg.day of a specified heavy metal.

$H Q=A D I / R f D$

For n number of heavy metals, the noncarcinogenic effect of the population is the summation of HQs due to different metals known as hazard index (HI).

$\mathrm{HI}=\sum \mathrm{HQ}=\sum \mathrm{ADI} / \mathrm{RfD} \ldots \ldots . . .[5]$

In a situation where the $\mathrm{HI}$ value is not up to 1, the exposed population is not likely to experience the occurrence of adverse health effects. Meanwhile, if the HI value is more than 1 , there might be issue regarding noncarcinogenic effects. The HQ which is the summation of average daily index by the reference dose is the independent variables while the $\mathrm{HI}$ depends on their outcome. 
Table 2: Parameters used for health risk assessment exposure

\begin{tabular}{|c|c|c|c|c|}
\hline Parameter & Unit & Adult & Children & Reference \\
\hline Exposure Freq. (EF) & days/year & 300 & 300 & This study \\
\hline Exposure Duration (ED) & years & 25 & 5 & This study \\
\hline Body weight & $\mathrm{Kg}$ & 60 & 15 & This study \\
\hline Inhalation Rate (IRair) & $\mathrm{m}^{3} /$ day & 37.38 & 28 & USEPA (2009) \\
\hline Exposure Time & $\mathrm{hr} /$ day & 3 & 3 & This study \\
\hline Ingestion Rate (IR) & $\mathrm{mg} /$ day & 100 & 200 & Kamunda et al. (2016) \\
\hline Skin surface area (SA) & $\mathrm{cm}^{2}$ & 5800 & 2100 & Kamunda et al. (2016) \\
\hline Soil adherence factor (AF) & $\mathrm{mg} / \mathrm{cm}^{2}$ & 0.07 & 0.2 & Kamunda et al. (2016) \\
\hline Dermal Absorption Factor (ABS) & none & 0.1 & 0.1 & Kamunda et al. (2016) \\
\hline Particulate emission factor (PEF) & $\mathrm{m}^{3} / \mathrm{kg}$ & $1.3 \otimes 10^{9}$ & $1.3 \varangle 10^{9}$ & Kamunda et al. (2016) \\
\hline Conversion factor (CF) & $\mathrm{Kg} / \mathrm{mg}$ & $10^{-6}$ & $10^{-6}$ & Kamunda et al. (2016) \\
\hline Average Time (AT) & days & $365 \star \mathrm{ED}$ & $365^{\star} \mathrm{ED}$ & This study \\
\hline For non-carcinogens & & $365 * 70$ & $365^{\star} 70$ & Kamunda et al. (2016) \\
\hline For carcinogens & & & & \\
\hline
\end{tabular}

\section{Cancer Risk Assessment}

The cancer risk is estimated as the possibility of a person developing a cancer over a lifetime exposure to potential contaminants.

Risk $_{\text {pathway }}=\sum$ ADI.CSF.......[6]

The Risk is a unitless value. ADI in ( $\mathrm{mg} / \mathrm{kg}$.day) and CSF in $(\mathrm{mg} / \mathrm{kg} \text {.day })^{-1}$, these are the average daily intake and the cancer slope factor of $\mathrm{n}$ heavy metals respectively. The average daily index and the cancer slope factor are the independent variables while the cancer risk depends on their outcome.

The total lifetime cancer risk was calculated from the input of different heavy metals in all the pathways as follows:

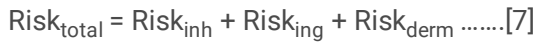

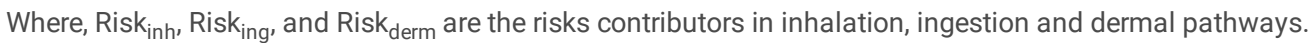

Table 3: Reference doses in mg/kg-day and cancer slope factor (CSF) for different heavy metals

\begin{tabular}{|c|c|c|c|c|c|c|}
\hline $\begin{array}{l}\text { Heavy } \\
\text { metals }\end{array}$ & $\mathrm{RfD}_{\text {inh }}$ & $\mathrm{RfD}_{\text {ing }}$ & $\mathrm{RfD}_{\text {derm }}$ & Inhalation CSF & Oral CSF & $\begin{array}{l}\text { Dermal } \\
\text { CSF }\end{array}$ \\
\hline $\begin{array}{l}\text { Cadmium } \\
\text { (Cd) }\end{array}$ & $\begin{array}{l}2.4 \otimes 10^{-6} \text { Liang et al. } \\
(2017)\end{array}$ & 5.00E-04 USEPA (1991) & $\begin{array}{l}5.70 \mathrm{E}-05 \text { USEPA } \\
(1991)\end{array}$ & $\begin{array}{l}6.30 \mathrm{E}+00 \text { Kamunda et } \\
\text { al. }(2016)\end{array}$ & - & - \\
\hline $\begin{array}{l}\text { Copper } \\
\text { (Cu) }\end{array}$ & $\begin{array}{l}4.02 \otimes 10^{-2} \text { Liang et al. } \\
(2017)\end{array}$ & $\begin{array}{l}\text { 3.7.00E-02 Kamunda et al. } \\
\text { (2016) }\end{array}$ & - & - & - & - \\
\hline Lead (Pb) & $\begin{array}{l}3.52 \otimes 10^{-3} \text { Liang et al. } \\
(2017)\end{array}$ & $\begin{array}{l}\text { 3.60E-03 Luo et al. } \\
(2012)\end{array}$ & - & $\begin{array}{l}\text { 4.20E-02 Kamunda et al. } \\
(2016)\end{array}$ & $\begin{array}{l}\text { 8.50E-03 Luo et al. } \\
(2012)\end{array}$ & - \\
\hline
\end{tabular}

\section{Results And Discussion}

The results revealed the rationale behind this study which is to ascertain the pollution level of e-waste activities (burning of e-waste at treatment points) posed to the extractors and the people around the treatment points. It reveals the concentration of heavy metals $(\mathrm{Cd}, \mathrm{Cu}$, and $\mathrm{Pb})$ there in, the concentration in relation to set threshold and the assessment of human health risks (carcinogenic and non-carcinogenic) people are exposed to.

The e-waste burning engaged by the extractors is solely for economic gain as valuable resources are extracted from the burnt materials which cater for the livelihoods of the extractors and their family. The government also gains from this activity by collecting tax and revenue from the extractors and agents that are engaged in e-waste activities. Notwithstanding, their activities pollute the environment and posed a threat to the well being of the extractors and the public residing around the treatment points. This is a thing of concern and has prompt for undertaking this study in order to safeguard the environment and the populace. 
The heavy metal concentrations were revealed and risk assessments for non-carcinogenic and carcinogenic ailments were analyzed.

Table 4: Heavy metal concentration at E-waste treatment points (Burning)

$$
\text { Locations of Treatment point (Burning) Cd Conc. (ppm) Cu Conc. (ppm) Pb Conc. (ppm) }
$$

\begin{tabular}{llll} 
Kuka Bulukiya & & & \\
\hline (0m) Sample 1 & 0.0025 & 0.0513 & 0.0775 \\
\hline (5m) Sample 2 & 0.0052 & 0.0512 & 0.0652 \\
\hline (10m) Sample 3 & 0.0051 & 0.0550 & 0.0651 \\
\hline Mean Conc. & 0.0042 & 0.0525 & 0.0693 \\
\hline$(100 \mathrm{~m})$ Control & 0.0015 & 0.0037 & 0.0052 \\
\hline PRP Gidan Ruwa & & & \\
\hline (0m) Sample 1 & 0.0075 & 0.0352 & 0.0070 \\
\hline (5m) Sample 2 & 0.0053 & 0.0412 & 0.0675 \\
\hline$(10 \mathrm{~m})$ Sample 3 & 0.0051 & 0.0325 & 0.0725 \\
\hline Mean Conc. & 0.0059 & 0.0363 & 0.049 \\
\hline$(100 \mathrm{~m})$ Control & $\mathrm{ND}$ & 0.0027 & 0.0097
\end{tabular}

ND $=$ Not Detected

The heavy metal concentration $(\mathrm{Cd}, \mathrm{Cu}$, and $\mathrm{Pb})$ is shown in Table 4 in the various samples analyzed at the two treatment points (Kuka Bulukiya and PRP $\mathrm{G} /$ Ruwa). The results of the analysis at Kuka Bulukiya treatment point revealed $\mathrm{Pb}$ has the highest mean concentration of $0.0693 \mathrm{ppm}$, followed by $\mathrm{Cu} 0.0525$ ppm and Cd having $0.0042 \mathrm{ppm}$. However, the control concentration of heavy metal was relatively lower than the concentration of the samples at the treatment points. Cd was found to be $0.0015 \mathrm{ppm}$, Cu was $0.0037 \mathrm{ppm}$, and $\mathrm{Pb}$ was $0.0052 \mathrm{ppm}$ respectively, this might not be unconnected with pollution from other sources within the urban environment. This implies that there are heavy metal pollution activities taking place at the treatment points, which is a thing of concern for the extractors, public and environmental health. The concentrations at PRP G/Ruwa was found to be similar to the one at Kuka Bulukiya but the mean concentration of $\mathrm{Cd}$ which was found to be $0.0059 \mathrm{ppm}$ is slightly (significant) more than the concentration at Kuka Bulukiya. However, the mean concentration of $\mathrm{Cu}$ which was $0.0363 \mathrm{ppm}$ and $\mathrm{Pb}$ which was $0.049 \mathrm{ppm}$ is slightly lower than the concentrations at Kuka Bulukiya as seen in Table 4 . The $\mathrm{Cu}$ concentration for control at PRP G/ruwa was found to be $0.0027 \mathrm{ppm}$ which was slightly lower and for Pb it was $0.0097 \mathrm{ppm}$ which was higher than the control concentration at Kuka Bulukiya respectively. However, Cd concentration at PRP G/Ruwa was not detected (ND), this implies that the concentration might be negligible and below the detection limit of the equipment. The result of the analysis (Table 4) in the two treatment points (K/Bulukiya and PRP $\mathrm{G} /$ Ruwa) is higher than the concentrations of $\mathrm{Cu} 2.468 \mu \mathrm{g} / \mathrm{m}^{3}(0.00247 \mathrm{ppm})$ and Cd $0.008 \mu \mathrm{g} / \mathrm{m}^{3}(0.000008 \mathrm{ppm})$ in the study of Kim et al. (2010) on the characteristics of atmospheric heavy metals in subway station in Seoul. This implies the contributions of e-waste burning materials in the results of the analysis obtained. However, the study of Adaramodu et al. (2012) on the concentration of metals of surface dust in e-waste components of the Westminister electronic market, Lagos for $\mathrm{Pb}$ (outdoor dust) $15.90 \mathrm{mg} / \mathrm{kg}$ and $\mathrm{Cd}$ (outdoor dust) $1.80 \mathrm{mg} / \mathrm{kg}$ is way higher than the result in this analysis (Table 4). Other similar studies on exposure to the heavy metals of e-waste workshops and recycling point are (Xu et al. 2015) and (Wu et al. 2016).

\section{Heavy metal concentration in relation to set threshold and its implications}

However, the result of the analysis in relation to NESREA standards for point source maximum emission limit for facilities and process, and for ambient air quality standards is shown in Table 5. The analysis discovered that the concentration of $\mathrm{Cd}, \mathrm{Cu}$, and $\mathrm{Pb}$ at the two treatment points (Kuka Bulukiya and PRP G/Ruwa) is lower than the NESREA (2014) set threshold for point source maximum emission limit for facilities and process from any source (Table 5). More so, the ambient air quality standards set by NESREA (2013) for concentration of $\mathrm{Cd}(0.38 \mathrm{ppm})$ and $\mathrm{Pb}(3759 \mathrm{ppm})$ is higher than the concentration of $\mathrm{Pb}$ $(0.063 \mathrm{ppm})$ and $(0.049 \mathrm{ppm})$, and Cd $(0.0042 \mathrm{ppm})$ and $(0.0059 \mathrm{ppm})$ at both Kuka Bulukiya and PRP G/Ruwa treatment points respectively. The USEPA (2016b) National Ambient Air Quality Standards (NAAQS) for lead stipulated the primary and secondary standards to be $0.15 \mu \mathrm{g} / \mathrm{m}^{3}$ for $3 \mathrm{months}$ average which is lower than the concentration obtained in this study for the two treatment points. European Commission (2000) assigned a 0.2 to $2.5 \mathrm{ng} / \mathrm{m}^{3} \mathrm{for}$ ambient air pollution by cadmium at urban background which is lesser than the mean concentration for the two treatment points in this study.

Of importance is the consideration for the extractors/collectors, public and environmental health that need to be checked (Plate 1). There is tendency of accumulation of these heavy metals over time which might result to myriad of health and environmental problems. Of concern is that there are lots of buildings (houses and schools) surrounding the treatment points at K/Bulukiya, a football field where football is played by both children and adults, children that comes to the pond to catch fish and swim, that inhale the burnt e-waste are at risk or might potentially face several health challenges (Plate 1). There is Kuka Bulukiya primary school and GJSS (Plate 1) nearby that houses children (which are vulnerable) during school hours while these burning (e-waste) activities takes place.

Table 5: Heavy metals concentration in air at e-waste treatment points in relation to NESREA threshold 


\begin{tabular}{llllll} 
& $\begin{array}{l}\text { Treatment } \\
\text { point }\end{array}$ & $\begin{array}{l}\text { Treatment } \\
\text { point }\end{array}$ & $\begin{array}{l}\text { NESREA (2014) point source max. } \\
\text { emission limit for facilities and process }\end{array}$ & & $\begin{array}{l}\text { NESREA (2013) } \\
\text { ambient air quality } \\
\text { standards }\end{array}$ \\
\hline pollutants & $\begin{array}{l}\text { Kuka } \\
\text { Bulukliya } \\
\text { conc. }(\mathrm{ppm})\end{array}$ & $\begin{array}{l}\text { PRP } \\
\text { G/Ruwa } \\
\text { conc. }(\mathrm{ppm})\end{array}$ & Standard applicable to source & $\begin{array}{l}\text { Maximum } \\
\text { permissible limit } \\
(\mathrm{ppm})\end{array}$ & $\begin{array}{l}\text { Time weighted average } \\
\text { Maximum } \\
\text { permissible limit } \\
(\mathrm{ppm})\end{array}$ \\
\hline Cadmium & 0.0042 & 0.0059 & Any source & 2.0 & 375 \\
\hline Copper & 0.0525 & 0.0363 & Any industrial source & 36 & annual \\
\hline Lead & 0.0693 & 0.049 & Any trade industry or process & 1.1 & annual
\end{tabular}

Source: Field survey (2020), NESREA (2014), NESREA (2013)

Of interest is that at PRP G/Ruwa treatment point during the burning of e-waste materials, air or smoke settles or moves over the nearby vegetable farmland which might lead to bioaccumulation of these metals $(\mathrm{Cd}, \mathrm{Cu}$, and $\mathrm{Pb})$ on the farm produce with the potential of causing unforeseen danger to the consumers and nearby houses. Liu et al. (2021) indicated that the results of a study conducted on heavy metals in soil/vegetable system close to e-waste site in China showed that both adults and children were suffering from health risk. It further narrated that the consumption of lettuce and sweet potato caused the most health risk and also revealed that cowpea and cabbage were moderately safe. Another study by Yin et al. (2021) revealed that there is a reasonable pollution of PBDEs and heavy metals there in the vegetables in a regulated e-waste recycling site, Eastern China.

Another public health implication of burning of e-waste materials in open place is that the extractors/collectors and people living around the area do not use any form of protection (face and hand gloves) for safety during burning and this poses a health related menace to the extractors, environment and the public.

However, it is worth noting that children residing close to PRP G/Ruwa treatment point especially, come to the treatment point to sell sachet water and in the process inhaling and ingesting the contaminants there in the burning activities and another activity worth noting is that there are wood cutters just about 1.5 $\mathrm{m}$ to the treatment point which this open burning will be a threat to their well being.

The major implication of these heavy metals is that they are toxic at low levels of exposure. In addition, both acute and chronic exposure are a threat to humans and the environment, that is a single exposure to harmful substances and those that occurs over a long period of time and that its health effects are cumulative. Similarly, they tend to build up in crucial organs like kidney, brain, liver, and bones, for number of years leading to serious health problems once they are absorbed by the body (Kamunda et al. 2016). The effect of over time accumulation of inhaled cadmium is adverse kidney, bone and liver damage, and cancer and for lead is delays in neurological development, physical development and damage, and damage of renal function, hearing loss, anaemia, and blood pressure (WHO 2007). Furthermore, Pb disturbs the functioning of kidneys, reproductive issue and the nervous system, and also induces renal tumor. Severe exposure to $\mathrm{Cd}$ has its effect such as emphysema, alveolitis, and bronciolitis (Pendias 2011). Cd may also lead to kidney malfunction, hypertension, bone fracture, and cancer (Khan et al. 2013). Anaemia, cardiovascular diseases, reduced fertility, arthritis, cirrhosis, and strokes are seen as some of its effect in a long run (Kamunda et al. 2016). Excessive exposure to Cu may lead to noncarcinogenic effects on human health, meanwhile they are crucial to human life, its surplus has been linked with liver damage (Cao et al. 2010).

\section{Health Risk Exposure Assessment}

The health risk exposure assessment in this study comprises of both noncarcinogenic and carcinogenic assessment of the health risk in the burning of ewaste materials at K/Bulukiya and PRP G/Ruwa treatment points. Exposure of the extractors and the people living around the treatment points that likely inhaled, ingested, and had dermal contact with the contaminated air is considered in this assessment. This assessment predicts the possible non-cancerous and cancerous health risk exposed by adult and children at both treatment points by integrating data generated (Table 2 and 3 ) to arrive at the estimates of hazard indices and cancer risk through different pathways (inhalation, ingestion, and dermal contact) of identified heavy metals (Cd, $\mathrm{Cu}$, and $\mathrm{Pb}$ ) there in.

\section{Noncarcinogenic Risk of Heavy Metals}

Based on the RfD values (Table 3) and ADI values (Table 6), the noncarcinogenic risk for adults and children were calculated. The results for the pathways (inhalation, ingestion, and dermal) were all expressed in terms of hazard quotient (HQs) and its summation expressed in terms of hazard indices ( $\mathrm{HI}$ ) in Table 6. The HQs and $\mathrm{HI}$ gave the prediction of the potential noncarcinogenic health risk exposed by the populace.

The standard is that when $\mathrm{HQ}$ and $\mathrm{HI}$ values are not up to 1 , it means there is no clear potential risk of noncarcinogenic effects to the population, though if these values surpass 1, there may be concerns (US EPA 2004). The result of the adult population calculated shows that the HQ (Figure 1, 2, 3 and 4) and $\mathrm{HI}$ values are less than 1 in all the pathways (inhalation, ingestion, and dermal) at both Kuka Bulukiya and PRP G/Ruwa treatment points (1.2 $₫ 10^{-4}$ and $9.8 \otimes 10^{-}$ ${ }^{5}$ ) respectively (Table 6).

Figure 1 and 2 shows the hazard quotient for Kuka Bulukiya for adult and children for all the pathways (inhalation, ingestion and dermal) and for the contaminants under study ( $\mathrm{Cd}, \mathrm{Pb}$ and $\mathrm{Cu})$. The standard for the values used in the conversion of the figures was $1 \otimes 10^{-6}$.

This meant that the populations are not at risk of noncarcinogenic effects. However, dermal and ingestion contributed more followed by inhalation in that order at both treatment points. In essence, the result for the children revealed that the $\mathrm{HQ}$ and $\mathrm{HI}$ are less than 1 , for all the pathways at both treatment points at Kuka Bulukiya $6.4 \otimes 10^{-4}$ and PRP G/Ruwa $5.9 \otimes 10^{-4}$ (Table 6). This meant children populations are not at risk of noncarcinogenic health effects based on the calculation of health risk assessment due to the concentration of the heavy metals in this study. 
Figure 3 and 4 shows the hazard quotient for PRP G/Ruwa for adult and children for all the pathways (inhalation, ingestion and dermal) and for the contaminants under study ( $\mathrm{Cd}, \mathrm{Pb}$ and $\mathrm{Cu}$ ). The standard for the values used in the conversion of the figures was $1 \mathbb{1 0} 10^{-6}$.

\subsubsection{Cancer Risk Assessment of Heavy Metals}

Based on the carcinogenic risk assessment values calculated, the lifetime average daily dose (LADD) values in Table 7 and cancer slope factor (CSF) in Table 2 revealed the health risk threat faced by the extractors and the public. The lifetime risk assessment for adults and children contributed by different heavy metals for all the pathways in Table 7 is shown.

The carcinogenic risk was calculated for $\mathrm{Cd}, \mathrm{Cu}$, and $\mathrm{Pb}$ where $\mathrm{Pb}$ was found to be the major contributor in this assessment (Figure 5, 6, 7 and 8). The US EPA (2004) considers $1 \otimes 10^{-6}$ to $1 \otimes 10^{-4}$ to be the range of the standard for cancer risk purposes. The cancer risk for Kuka Bulukiya $6 \nabla 10^{-10}$ and PRP G/Ruwa $5 \otimes$ $10^{-10}$ for adults and $7 \otimes 10^{-10}$ and $4 \otimes 10^{-10}$ for children (Table 7) were both lower than the threshold set for cancer risk. Figure 5 and 6 shows the cancer risk potential for Kuka Bulukiya for adult and children for all the pathways (inhalation, ingestion and dermal) and for the contaminants under study (Cd, $\mathrm{Pb}$ and Cu). The standard for the values used in the conversion of the figures was $1010^{-9}$.

This meant that both adults and children are not at risk of cancer based on the assessment in this study at the treatment points. The ingestion contributed more to cancer risk assessment then followed by inhalation pathway. However, due to the non-availability of cancer slope factor (CSF) for the dermal pathway it was not part of the assessment. Though, there is need for caution since there is hazard identification at the treatment points and authorities should act accordingly.

Figure 7 and 8 shows the cancer risk for PRP G/Ruwa for adult and children for all the pathways (inhalation, ingestion and dermal) and for the contaminants under study $(\mathrm{Cd}, \mathrm{Pb}$ and $\mathrm{Cu})$. The standard for the values used in the conversion of the figures was $1 \mathrm{Q} 10^{-9}$.

Lead toxicity is apparent as it contributes more in the results revealed followed by cadmium, and copper contributed the least in the calculation at both Kuka Bulukiya and PRP G/Ruwa treatment points

Table 6: Average Daily Intake (ADI) Values in mg/kg.day, Hazard Quotient (HQ) and Hazard Index (HI) for Adults and Children at the E-waste Buming Sites for Noncarcinogenic Risk Calculations

\begin{tabular}{|c|c|c|c|c|c|c|c|c|c|c|c|c|c|}
\hline $\begin{array}{l}\text { Heavy } \\
\text { metals }\end{array}$ & $A D I_{\text {inh }}$ Adult & $\begin{array}{l}\mathrm{ADI}_{\text {ing }} \\
\text { Adult }\end{array}$ & $\begin{array}{l}\text { ADI }_{\text {derm }} \\
\text { Adult }\end{array}$ & $\begin{array}{l}\mathrm{ADI}_{\text {inh }} \\
\text { Children }\end{array}$ & $\begin{array}{l}\mathrm{ADI}_{\text {ing }} \\
\text { Children }\end{array}$ & $\begin{array}{l}\mathrm{ADI}_{\text {derm }} \\
\text { Children }\end{array}$ & $\mathrm{HQ}_{\text {inh }}$ Adult & $\begin{array}{l}\mathrm{HQ}_{\text {ing }} \\
\text { Adult }\end{array}$ & $\begin{array}{l}\mathrm{HQ}_{\text {derm }} \\
\text { Adult }\end{array}$ & $\begin{array}{l}\mathrm{HQ}_{\text {inh }} \\
\text { Children }\end{array}$ & $\begin{array}{l}\mathrm{HQ}_{\text {ing }} \\
\text { Children }\end{array}$ & $\begin{array}{l}\mathrm{HQ}_{\text {derm }} \\
\text { Children }\end{array}$ & $\begin{array}{l}\mathrm{HI} \\
\mathrm{Ac}\end{array}$ \\
\hline \multicolumn{14}{|c|}{ K/Bulukiya } \\
\hline $\mathrm{Cd}$ & $4.74 \otimes 10^{-12}$ & $\begin{array}{l}5.8 \otimes \\
10^{-9}\end{array}$ & $\begin{array}{l}2.3 \otimes \\
10^{-9}\end{array}$ & $\begin{array}{l}1.42 \rrbracket \\
10^{-11}\end{array}$ & $\begin{array}{l}4.6 \otimes 10^{-} \\
8\end{array}$ & $\begin{array}{l}9.7 \otimes 10^{-} \\
9\end{array}$ & $1.9 \otimes 10^{-6}$ & $\begin{array}{l}1.2 \otimes \\
10^{-5}\end{array}$ & $\begin{array}{l}4.6 \otimes \\
10^{-6}\end{array}$ & $\begin{array}{l}5.9 \otimes 10^{-} \\
6\end{array}$ & $\begin{array}{l}9.2 \otimes 10^{-} \\
5\end{array}$ & $\begin{array}{l}1.9 \otimes 10^{-} \\
\end{array}$ & $\begin{array}{l}1 . \\
16\end{array}$ \\
\hline $\mathrm{Cu}$ & $5.93 \otimes 10^{-11}$ & $\begin{array}{l}7.2 \otimes \\
10^{-9}\end{array}$ & $\begin{array}{l}2.9 \otimes \\
10^{-8}\end{array}$ & $\begin{array}{l}1.78 \rrbracket \\
10^{-10}\end{array}$ & $\begin{array}{l}5.8 \otimes 10^{-} \\
7\end{array}$ & $\begin{array}{l}1.2 \otimes 10^{-} \\
7\end{array}$ & $1.5 \otimes 10^{-9}$ & $\begin{array}{l}1.9 \otimes \\
10^{-7}\end{array}$ & $\begin{array}{l}1.2 \otimes \\
10^{-6}\end{array}$ & $\begin{array}{l}2 \otimes 10^{-} \\
10\end{array}$ & $\begin{array}{l}1.6 \otimes 10^{-} \\
6\end{array}$ & $\begin{array}{l}5.0 \otimes 10^{-} \\
6\end{array}$ & $\begin{array}{l}1 . \\
16\end{array}$ \\
\hline $\mathrm{Pb}$ & $7.92 \otimes 10^{-11}$ & $\begin{array}{l}9.5 \otimes \\
10^{-8}\end{array}$ & $\begin{array}{l}3.85 \rrbracket \\
10^{-8}\end{array}$ & $\begin{array}{l}2.35 \bigotimes \\
10^{-10}\end{array}$ & $\begin{array}{l}7.6 \otimes 10^{-} \\
7\end{array}$ & $\begin{array}{l}1.6 \otimes 10^{-} \\
\end{array}$ & $2.3 \otimes 10^{-8}$ & $\begin{array}{l}2.6 \otimes \\
10^{-5}\end{array}$ & $\begin{array}{l}7.3 \otimes \\
10^{-5}\end{array}$ & $\begin{array}{l}6.7 \otimes 10^{-} \\
8\end{array}$ & $\begin{array}{l}2.1 \otimes 10^{-} \\
4\end{array}$ & $\begin{array}{l}3.0 \otimes 10^{-} \\
4\end{array}$ & $\begin{array}{l}9 . \\
16\end{array}$ \\
\hline Total & - & - & - & - & - & - & $1.9 \otimes 10^{-6}$ & $\begin{array}{l}3.8 \otimes \\
10^{-5}\end{array}$ & $\begin{array}{l}7.8 \otimes \\
10^{-5}\end{array}$ & $\begin{array}{l}5.9 \otimes 10^{-} \\
6\end{array}$ & $\begin{array}{l}3.0 \otimes 10^{-} \\
4\end{array}$ & $\begin{array}{l}6.3 \otimes 10^{-} \\
4\end{array}$ & $\begin{array}{l}1 . \\
16\end{array}$ \\
\hline \multicolumn{14}{|c|}{$\begin{array}{l}\text { PRP } \\
\text { G/Ruwa }\end{array}$} \\
\hline $\mathrm{Cd}$ & $6.67 \otimes 10^{-12}$ & $\begin{array}{l}8.1 \mathrm{Q} \\
10^{-9}\end{array}$ & $\begin{array}{l}3.28 \rrbracket \\
10^{-9}\end{array}$ & $\begin{array}{l}1.99 \rrbracket \\
10^{-11}\end{array}$ & $\begin{array}{l}6.8 \otimes 10^{-} \\
8\end{array}$ & $\begin{array}{l}1.4 \otimes 10^{-} \\
8\end{array}$ & $2.8 \otimes 10^{-6}$ & $\begin{array}{l}1.6 \\
\otimes 10^{-5}\end{array}$ & $\begin{array}{l}6.6 \\
\otimes 10^{-6}\end{array}$ & $\begin{array}{l}8.3 \otimes 10^{-} \\
6\end{array}$ & $\begin{array}{l}1.4 \otimes 10^{-} \\
4\end{array}$ & $\begin{array}{l}2.7 \otimes 10^{-} \\
5\end{array}$ & $\begin{array}{l}2 . \\
\otimes 1\end{array}$ \\
\hline $\mathrm{Cu}$ & $4.1 \otimes 10^{-11}$ & $\begin{array}{l}4.97 \rrbracket \\
10^{-8}\end{array}$ & $\begin{array}{l}2.02 \rrbracket \\
10^{-8}\end{array}$ & $\begin{array}{l}1.23 \mathbb{Q} \\
10^{-10}\end{array}$ & $\begin{array}{l}3.9 \otimes 10^{-} \\
7\end{array}$ & $\begin{array}{l}8.4 \otimes 10^{-} \\
8\end{array}$ & $1.0 \otimes 10^{-9}$ & $\begin{array}{l}1.3 \\
\otimes 10^{-6}\end{array}$ & $\begin{array}{l}8.4 \\
\otimes 10^{-7}\end{array}$ & $\begin{array}{l}3.0 \otimes 10^{-} \\
8\end{array}$ & ${ }_{5} .0 \otimes 10^{-}$ & $\begin{array}{l}3.5 \otimes 10^{-} \\
6\end{array}$ & $\begin{array}{l}2 . \\
\otimes 1\end{array}$ \\
\hline $\mathrm{Pb}$ & $5.53 \otimes 10^{-11}$ & $\begin{array}{l}6.71 \rrbracket \\
10^{-8}\end{array}$ & $\begin{array}{l}2.73 \otimes \\
10^{-8}\end{array}$ & $\begin{array}{l}1.66 \rrbracket \\
10^{-10}\end{array}$ & $\begin{array}{l}5.4 \otimes 10^{-} \\
7\end{array}$ & $\begin{array}{l}1.3 \otimes 10^{-} \\
7\end{array}$ & $1.6 \otimes 10^{-8}$ & $\begin{array}{l}1.9 \\
\otimes 10^{-5}\end{array}$ & 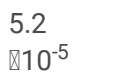 & $\begin{array}{l}4.7 \otimes 10^{-} \\
8\end{array}$ & $\begin{array}{l}1.5 \otimes 10^{-} \\
4\end{array}$ & $\begin{array}{l}2.5 \otimes 10^{-} \\
4\end{array}$ & $\begin{array}{l}7 . \\
\otimes 1\end{array}$ \\
\hline Total & - & - & - & - & - & - & $2.8 \otimes 10^{-6}$ & $\begin{array}{l}3.6 \otimes \\
10^{-5}\end{array}$ & 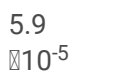 & $\begin{array}{l}8.4 \otimes 10^{-} \\
6\end{array}$ & $\begin{array}{l}3.0 \otimes 10^{-} \\
4\end{array}$ & $\begin{array}{l}2.8 \otimes 10^{-} \\
4\end{array}$ & $\begin{array}{l}9 . \\
\otimes 1\end{array}$ \\
\hline
\end{tabular}

Table 7: Lifetime Average Daily Dose (LADD) in mg/kg.day and Hazard Cancer Risk for Adult and Children at E-waste Material Burning Sites for Carcinogenic Calculations 


\begin{tabular}{|c|c|c|c|c|c|c|c|c|c|}
\hline $\begin{array}{l}\text { Heavy } \\
\text { metals }\end{array}$ & $\mathrm{LADD}_{\text {inh }}$ Adult & $\mathrm{LADD}_{\text {ing }}$ Adult & $\mathrm{LADD}_{\text {derm }}$ Adult & $\mathrm{LADD}_{\text {inh }}$ Children & $\mathrm{LADD}_{\text {ing }}$ Children & $\mathrm{LADD}_{\text {derm }}$ Children & $\begin{array}{l}\text { Cancer } \\
\text { Risk }_{\text {inh }} \\
\text { Adullt }\end{array}$ & $\begin{array}{l}\text { Cancer } \\
\text { Risking }_{\text {ing }} \\
\text { Adult }\end{array}$ & $\begin{array}{l}\text { Canc } \\
\text { Risk }_{d} \\
\text { Adult }\end{array}$ \\
\hline \multicolumn{10}{|c|}{ K/Bulukiya } \\
\hline $\mathrm{Cd}$ & $1.7 \otimes 10^{-11}$ & $2.1 \otimes 10^{-9}$ & $8 \otimes 10^{-10}$ & $1.0 \otimes 10^{-12}$ & $3.3 \otimes 10^{-9}$ & $6.0 \bigotimes 10^{-8}$ & $\begin{array}{l}1.0 \otimes \\
10^{-10}\end{array}$ & - & - \\
\hline $\mathrm{Cu}$ & $2.1 \otimes 10^{-10}$ & $2.6 \rrbracket 10^{-8}$ & $1.1 \otimes 10^{-8}$ & $1.3 \otimes 10^{-11}$ & $4.1 \otimes 10^{-8}$ & $8.6 \otimes 10^{-9}$ & - & - & - \\
\hline $\mathrm{Pb}$ & $3.0 \otimes 10^{-10}$ & $5.2 \otimes 10^{-8}$ & $1.4 \otimes 10^{-8}$ & $1.7 \otimes 10^{-11}$ & $5.4 \otimes 10^{-8}$ & $1.4 \otimes 10^{-8}$ & $\begin{array}{l}1.3 \otimes \\
10^{-10}\end{array}$ & $\begin{array}{l}4 \otimes 10^{-} \\
10\end{array}$ & - \\
\hline Total & - & - & - & - & - & - & $\begin{array}{l}2 \otimes 10^{-} \\
10\end{array}$ & $\begin{array}{l}4 \otimes 10^{-} \\
10\end{array}$ & - \\
\hline \multicolumn{10}{|c|}{$\begin{array}{l}\text { PRP } \\
\text { G/Ruwa }\end{array}$} \\
\hline $\mathrm{Cd}$ & $2.4 \rrbracket 10^{-11}$ & $2.9 \otimes 10^{-9}$ & $1.2 \otimes 10^{-9}$ & $1.4 \otimes 10^{-11}$ & $4.6 \otimes 10^{-9}$ & $1.0 \otimes 10^{-9}$ & $\begin{array}{l}1.0 \bigotimes \\
10^{-10}\end{array}$ & - & - \\
\hline $\mathrm{Cu}$ & $1.5 \otimes 10^{-10}$ & $1.8 \otimes 10^{-8}$ & $7.2 \otimes 10^{-9}$ & $8.7 \otimes 10^{-11}$ & $2.8 \otimes 10^{-8}$ & $6.0 \otimes 10^{-9}$ & - & - & - \\
\hline $\mathrm{Pb}$ & $1.9 \otimes 10^{-10}$ & $2.4 \otimes 10^{-8}$ & $9.7 \otimes 10^{-9}$ & $1.2 \otimes 10^{-10}$ & $3.8 \otimes 10^{-8}$ & $8.1 \otimes 10^{-9}$ & $\begin{array}{l}2.0 \bigotimes \\
10^{-10}\end{array}$ & $\begin{array}{l}2 \otimes 10^{-} \\
10\end{array}$ & - \\
\hline Total & - & - & - & - & - & - & $\begin{array}{l}3 \otimes 10^{-} \\
10\end{array}$ & $\begin{array}{l}2 \otimes 10^{-} \\
10\end{array}$ & - \\
\hline
\end{tabular}

\section{Climate Change Adaptation}

This study has highlighted the threat posed by burning of e-waste materials and this contributes to climate change due to the chemicals released. This implies that the released chemicals (heavy metals, polybrominated biphenyls and toxins) accumulate in the air and posed severe health implications to the environment, humans and animals. E-waste being a contemporary area of study has limited studies on its activities adaptation to climate change. Climate change adaptation has to do with an environmentally friendly method of extracting valuable materials that should be at the forefront of policies that will be specifically enacted on e-waste management in developing countries. Taking back system and encouraging environmentally sound recycling and refurbishing alternatives will help in climate adaptation. Regulations should be in place to promote sustainable e-waste dismantling, extraction (by discouraging or stopping open burning of e-waste) facility and on how to capture the contaminants released into the air. Tree planting should be encouraged and a formal ewaste treatment points should be identified and allow only environmentally friendly activities to take place, and a penalty should be set aside for policy and regulation averters.

\section{Conclusion And Recommendation}

The results of this study and the discussion there in have highlighted the hazard caught up in open e-waste materials burning and their environmental implications and public health concerns. Though, the concentration was found to be below the set threshold by NESREA there is need for caution and regulations in informal open e-waste materials burning. The Health risk assessment calculated have revealed for now there is no non-carcinogenic and carcinogenic concerns with respect to the extractors and people living around the treatment points for both adults and children. The study concluded that informal burning of e-waste has substantially led to the relatively high levels of air pollution identified in the treatment points and in turn posed environmental and public health threat to the extractors and residents around the area. This research served as a wake-up call to the authorities in setting up a standard treatment points with the extractors, public and environmental health concerns in mind and a call for enforcement of regulations or its enactment in study area. The limitation is that the study had wanted to use a hands-on instrument that will measure the concentration of heavy metals at the spot (treatment points) but was unavailable. Specific e-waste management policies (dismantling, extraction, recycling facility and refurbishment) should be in place and enforced to curtail future consequences of e-waste activities.

\section{Declarations}

\section{Ethics approval and consent to participate}

This study neither involved human/animal participation, experiment, nor human data/tissue.

\section{Consent for publication}

This study did not involve children or individual details, but $100 \%$ data usage.

\section{Data availability statement}


All data generated or analysed during the study are included in the published article(s) cited within the text and acknowledged in the reference section.

\section{Competing interest}

All authors declare no competing interest.

\section{Funding}

The study was funded by the Tertiary Education Trust Fund, Nigeria (TETFUND).

\section{Contribution of authors}

Ahmed Abubakar, Aminu Sulaiman Zangina, Amina Sheikh Abdullahi and Jamilu Adamu Haruna contributed in the sourcing of relevant data, sample collection, sample preparation and analysis as well as synthesis, organisation, and drafting of the manuscript.

Dr. Mohd Yusoff Ishak, Dr. Murtala Muhammad Badamasi and Prof. Ahmed Ibrahim Maigari, critically reviewed the manuscript with addition and subtraction where necessary.

\section{Acknowledgment}

I wish to acknowledge Dr. Muhd Yusoff for providing access to turintin software to check similarity index. I am indebted to Dr Mohd Yussof Ishak, Dr. Murtala Muhammed Badamasi and Prof. Ahmed Ibrahim Maigari for their critical review towards this work.

\section{References}

1. Adaramodu AA, Osuntogun AO, Ehi-Eromosele CO (2012) Heavy Metal Concentration of Surface Dust Present in E-Waste Components: The Westminister Electronic Market, Lagos Case Study. Resources and Environment 2(2):9-13. http://journal.sapub.org/re

2. Alcántara-Concepción V, Gavilán-García A, Gavilán-García IC (2016) Environmental impacts at the end of life of computers and their management alternatives in México. J Clean Prod 131:615-628. https://doi.org/10.1016/j.jclepro.2016.04.125

3. Awasthi AK, Zeng X, Li J (2016) Environmental pollution of electronic waste recycling in India: a critical review. Environ Pollut 211:259-270. https://doi.org/10.1016/j.envpol.2015.11.027

4. Bakhiyi B, Gravel S, Ceballos D, Flynn MA, Zayed J (2018) Has the question of e-waste opened a Pandora's box? An overview of unpredictable issues and challenges. Environ Int 110:173-192. https://doi.org/10.1016/j.envint.2017.10.021

5. Bungadaeng S, Prueksasit T, Siriwong W (2019) Inhalation exposure to respirable particulate matter among workers in relation to their e-waste open burning activities in Buriram Province, Thailand. Sustainable Environment Research 29:26. https://doi.org/10.1186/s42834-019-0030-7

6. Cao H, Chen J, Zhang J (2010) Heavy metals in rice and garden vegetables and their potential health risks to inhabitants in the vicinity of an industrial zone in Jiangsu, China. Journal of Environmental Science 22:1792-1799. [crossRef]

7. Cao P, Fujimori T, Juhasz A, Takaoka M, Oshita K (2020) Bioaccessibility and human health risk assessment of metal (loid)s in soil from an e-waste open burning site in Agbogbloshie, Accra, Ghana. Chemosphere 240:124909. DOI: 10.1016/j.chemosphere.2019.124909

8. Ceballos DM, Dong Z (2016) The formal electronic recycling industry: challenges and opportunities in occupational and environmental health research. Environ Int 95:157-166. https://doi.org/10.1016/j.envint.2016.07.010

9. Cesaro A, Belgiorno V, Gorrasi G, Viscusi G, Vaccari M, Vinti G, Jandric A, Dias MI, Hursthouse A, Salhofer S (2019) A relative risk assessment of the open burning of WEEE. Environ Sci Pollut Res 26:11042-11052. https://doi.org/10.1007/s11356-019-04282-3

10. Chen H, Lam JC, Zhu M, Wang F, Zhou W, Du B, Zeng L, Zeng EY (2018) Combined effects of dust and dietary exposure of occupational workers and local residents to short-and medium-chain chlorinated paraffins in a mega E-waste recycling industrial park in South China. Environ. Sci. Technol. 52:1151011519. http://refhub.elsevier.com/S0160-4120(19)34136-4/h0015

11. Cucchiella F, D'Adamo I, Lenny Koh SC, Rosa P (2015) Recycling of WEEEs: an economic assessment of present and future e-waste streams. Renewable and Sustainable Energy Review 51:263-272. https://doi.org/10.1016/j.rser.2015.06.010

12. Dave SR, Shah MB, Tipre DR (2016) E-waste: Pollution Threat or Metal Resources? Journal of Advanced Research in Biotechnology 1(2):14. DOI: http://dx.doi.org/10.15226/2475-4714/1/2/00103

13. European Commission (2000) Ambient Air Pollution by As, Cd, and Ni compounds, final version. Office for official publication of European Communities. Http://europa.eu.int/comm/environment/pubs/home.htm

14. Forti V, Balde CP, Kuehr R, Bel G (2020) The Global E-waste Monitor: Quantities, flows and the circular economy potential. United Nations University (UNU)/United Nations Institute for Training and Research (UNITAR) - co-hosted SCYCLE Programme, International Telecommunication Union (ITU) \& International Solid Waste Association (ISWA), Bonn/Geneva/Rotterdam. https://www.itu.int/en/ITU-

D/Environment/Documents/Toolbox/GEM_2020_def.pdf

15. Gangwar C, Choudhari R, Chauhan A, Kumar A, Singh A, Tripathi A (2019) Assessment of air pollution caused by illegal e-waste burning to evaluate the human health risk. Environ Int 125:191-199. https://doi.org/10.1016/j.envint.2018.11.051

16. Ghosh B, Ghosh MK, Parhi P, Mukherjee PS, Mishra BK (2015) Waste printed circuit boards recycling: an extensive assessment of current status. J Clean Prod 94:5-19. https://doi.org/10.1016/j.jclepro.2015.02.024 
17. Huang DY, Zhou SG, Hong W, Feng WF, Tao L (2013) Pollution characteristics of volatile organic compounds, polycyclic aromatic hydrocarbons and phthalate esters emitted from plastic wastes recycling granulation plants in Xingtan Town, South China. Atoms Environment 71: $327-334$.

http://refhub.elsevier.com/S0160-4120(19)34136-4/h0060

18. Ikhlayel M (2018) An Integrative Approach to Develop E-Waste Management Systems for Developing Countries. J Clean Prod 170:119-130. doi: https://10.1016/j.jclepro.2017.09.137

19. Imran M, Haydar S, Kim J, Awan MR, Bhatti AA (2017) E-waste flows, resource recovery and improvement of legal framework in Pakistan. Resour Conserv Recycl 125:131-138. https://doi.org/10.1016/j.resconrec.2017.06.015

20. Kamunda C, Mathuthu M, Madhuku M (2016) Health risk assessment of heavy metals in soils from Witwatersrand Gold Miming Basin, South Africa. Int J Environ Res Public Health 13:663. http://10.3390/ijerph13070663

21. Khan K, Lu Y, Khan H (2013) Heavy metals in agricultural soils and crops and their health risks in Swat District, northern Pakistan. Food Chem Toxicol 58:449-458. [crossRef] [PubMed]

22. Kim CH, Yoo DC, Kwon YM, Han WS, Kim GS (2010) A Study of Characteristics of Atmospheric Heavy Metals in Subway Station. Toxicology Resources 26(2):157-162. http://www.toxmut.or.kr

23. Kumar AM, Prakash D (2019) Risk Assessment Environmental Impact of E-Waste Management. International Journal of Engineering Science and Computing 9(5):22193-22202. http://ijesc.org/

24. Liang Y, Yi X, Dang Z, Wang Q, Luo H, Tang J (2017) Heavy Metal Contamination and Health Risk Assessment in the Vicinity of a Tailing Pond in Guangdong, China. Int J Environ Res Public Health 14:1557:1-17. http://doi:10.3390/ijerph14121557

25. Li Y, Xu X, Liu J, Wu K, Gu C, Shao G, Chen S, Chen G, Huo X (2008) The hazard of chromium exposure to neonates in Guiyu of China. Sci Total Environ 403(1-3):99-104. Doi: https://10.1016/j.scitotenv.2008.05.033

26. Li J, Li W, Gao X, Liu L, Shen M, Chen H, Zhu M, Zeng L, Zeng EY (2020) Occurrence of multiple classes of emerging photoinitiators in indoor dust from Ewaste recycling facilities and adjacent communities in South China and implications for human exposure. Environ Int 136:105462. https://doi.org/10.1016/j.envint.2020.105462

27. Liu X, Gu S, Yang S, Deng J, Xu J (2021) Heavy metals in soil-vegetable system around e-waste site and health risk assessment. Science of the Total Environmen 779:146438. DOI: https://10.1016/j.scitotenv.2021.146438

28. Luo C, Liu C, Wang Y, Liu X, Li F, Zhang G, Li X (2011) Heavy metal contamination in soils and vegetables near an e-waste processing site, south China. J Hazard Mater 186(1):481-490. DOI: 10.1016/j.jhazmat.2010.11.024

29. Luo DY, Ding J, Xu B (2012) Incorporating bioaccessibility into human health risk assessment of heavy metals in urban park soils. Science of Total Environment 424:88-96. [Crossref][PubMed]

30. Monika and Jugal Kishore (2010) E-waste management: as a challenge to public health in India. Ind J Comm Med Indian Journal of Community Medicine 35(3):382-385. Doi: https://10.4103/0970-0218.69251

31. Mowla M, Rahman E, Prottoy HM, Ahmed SI, Aich N, Islam N (2019) Health risk assessment of heavy metals in E-waste recycling shops in Dhaka, Bangladesh. Proceedings, International Conference on Engineering Research and Practice 90-95. https://www.researchgate.net/publication/331558653

32. NESREA (2014) National Environmental (Air Quality Control) Regulations, 2014. Published by the Federal Government of Nigeria 101(142):1-25

33. NESREA (2013) Environmental (Air Quality Control) Regulations Draft, 2013. Published by the Federal Government of Nigeria, 1-25

34. Ngo HTT, Watchalayann P, Nguyen DB, Doan HN, Liang L (2020) Environmental Health Risk Assessment of Heavy Metal Exposure among Children Living in an Informal E-waste Processing Village in Vietnam. Sci Total Environ. https://doi.org/10.1016/j.scitotenv.2020.142982. 1-38

35. Oguri T, Suzuki G, Matsukami H, Uchida N, Tue NM, Tuyen L, Viet PH, Takahashi S, Tanabe S, Takigami H (2017) Exposure assessment of heavy metals in an e-waste processing area in northern Vietnam. Sci Total Environ 1-9. https://doi.org/10.1016/j.scitotenv.2017.10.115

36. Padiyar N (2011) Nickel allergy-is it a cause of concern in everyday dental practice. International Journal of Contemporary Dentistry 2(1):80-81. https://www.reserchgate.net/publication/48332710

37. Pendias K (2011) A trace elements in Soil and Plants, 4th edn. Boca Raton, FL, USA, Taylor and Francis

38. Perkins DN, Brune Drisse M-N, Nxele T, Sly PD (2014) E-waste: a global hazard. Ann Glob Health 80:286-295. https://doi.org/10.1016/j.aogh.2014.10.001

39. Priyadarshini S, Meenambal T (2011) A survey on electronic waste management in Coimbatore. International Journal of Engineering Science and Technology 3(3):2099-2104. https://Pdfs.semanticscholar.org

40. Shen M, Ge J, Lam JC, Zhu M, Li J, Zeng L (2019) Occurrence of two novel triazine-based flame retardants in an E-waste recycling area in South China: Implication for human exposure. Science of the Total Environment 683:249-257. http://refhub.elsevier.com/S0160-4120(19)34136-4/h0205

41. Singh M, Thind PS, John S (2018) Health risk assessment of the workers exposed to the heavy metals in e-waste recycling sites of Chandigarh and Ludhiana, Punjab, India. Chemosphere 1-16. doi: https://10.1016/j.chemosphere.2018.03.138

42. Tsydenova O, Bengtsson M (2011) Chemical hazards associated with treatment of waste electrical and electronic equipment. Waste Manag $31: 45-58$. doi: https://10.1016/j.wasman.2010.08.014

43. U.S. Environmental Protection Agency (1989) Risk Assessment Guidance for Superfund Volume 1: Human Health Evaluation Manual (Part A); Office of Emergency and Remedial Response: Washington, DC, USA

44. US Environmental Protection Agency (1991) Human Health Evaluation Manual, Supplemental Guidance: Standard Default Exposure Factors. USEPA, Washington, DC, USA 
45. US Environmental Protection Agency (2004) Risk Assessment Guidance for Superfund Volume 1: Human Health Evaluation Manual. part E, Supplemental Guidance for Risk Assessment); USEPA: Washington, DC, USA

46. US Environmental Protection Agency (2009) Metabolically Derived Human Ventilation Rates: a revised approach based upon oxygen consumption rates. National Centre for Environmental Assessment, Washington, DC; EPA/1600/R-06/129F

47. US EPA (2016b) National Ambient Air Quality Standards for Lead Reviewed based 2008 standards. Accessed on 1st October, 2020 from epa.gov

48. US EPA (2016a) Digestion for Total Metals in Water-Perspective. Lab Manual Section. Revision Date December, 2016. www.bc_lab_manual_total_metals_in_water_method.pdf

49. Vats MC, Singh SK (2014) Status of E-waste in India- A Review. International Journal of Innovative Research in Science, Engineering and Technology 3(10):16917-16931. https://10.15680/IJIRSET.2014.0310071

50. World Health Organization (2007) Health Risks of heavy metals from long range transboundry air pollution. Publication of the WHO regional office for Europe,1-144. http://www.euro.who.int/pubrequest

51. Wu Y, Li Y, Kang D, Wang J, Zhang Y, Du D, Pan B, Lin Z, Huang C, Dong Q (2016) Tetrabromobisphenol A and heavy metal exposure via dust ingestion in an e-waste recycling region in Southeast China. Sci Total Environ 541:356-364. http://dx.doi.org/10.1016/j.scitotenv.2015.09.038

52. Xu F, Liu Y, Wang J, Zhang G, Zhang W, Liu L, Wang J, Pan B, Lin K (2015) Characterization of heavy metals and brominated flame retardants in the indoor and outdoor dust of e-waste workshops: implication for on-site human exposure. Environ Sci Pollut Res 22:5469-5480. http://doi:10.1007/s11356-0143773-z

53. Yin H, Ma J, Li Y, Meng T, Tang Z (2021) Polybrominated Diphenyl Ethers and Heavy Metals in a Regulated E-waste Recycling Site, Eastern China: Implications for Risk Management. Molecules 26:2169. https://doi.org/10.3390/

54. Zhang T, Ruan J, Zhang B, Lu S, Gao C, Huang L, Bai X, Xie L, Gui M, Qiu R (2019) Ecotoxicol Environ Saf 169:707-713. https://doi.org/10.1016/j.ecoenv.2018.10.039

\section{Plate}

Plate 1 is available in the Supplemental Files section.

\section{Figures}

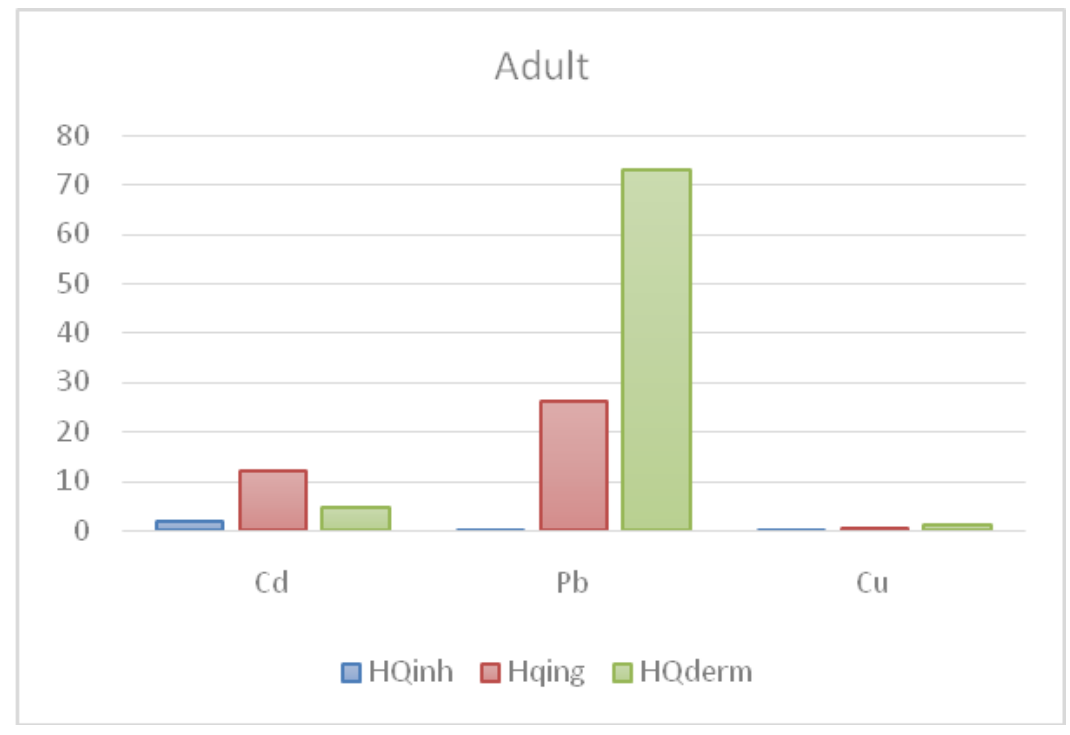

\section{Figure 1}

Adult Hazard Quotient (HQ's) for K/Bulukiya for all the pathways 


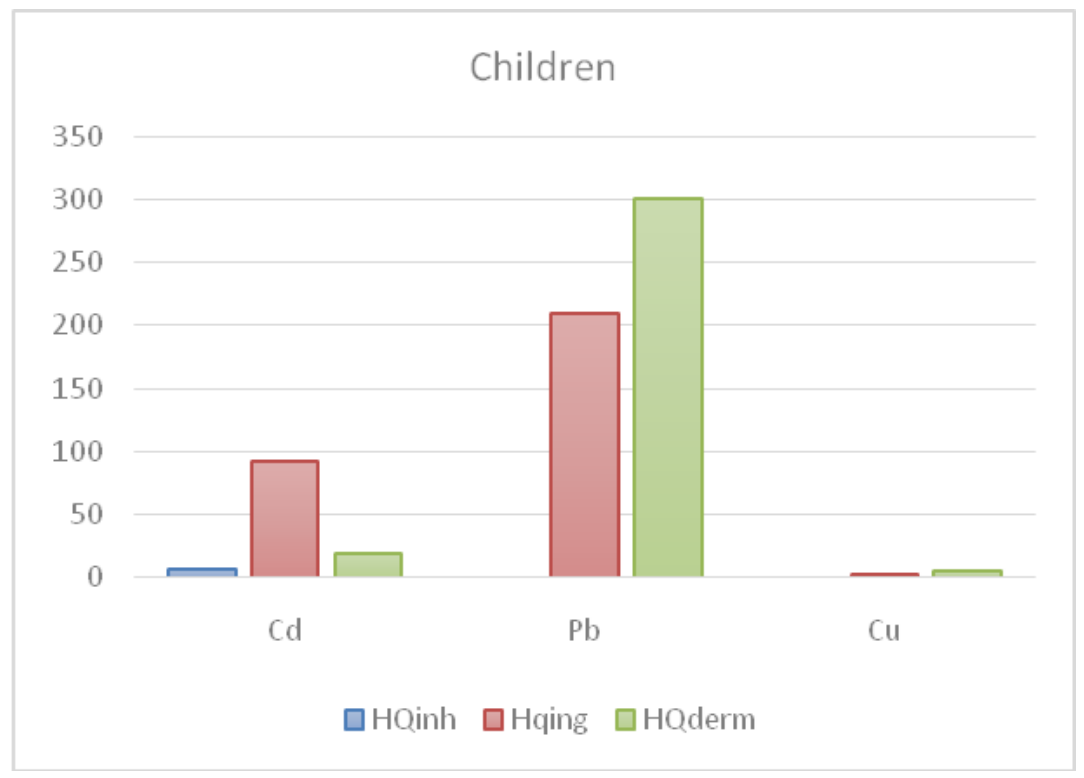

\section{Figure 2}

Children Hazard Quotient (HQ's) for K/Bulukiya for all the pathways

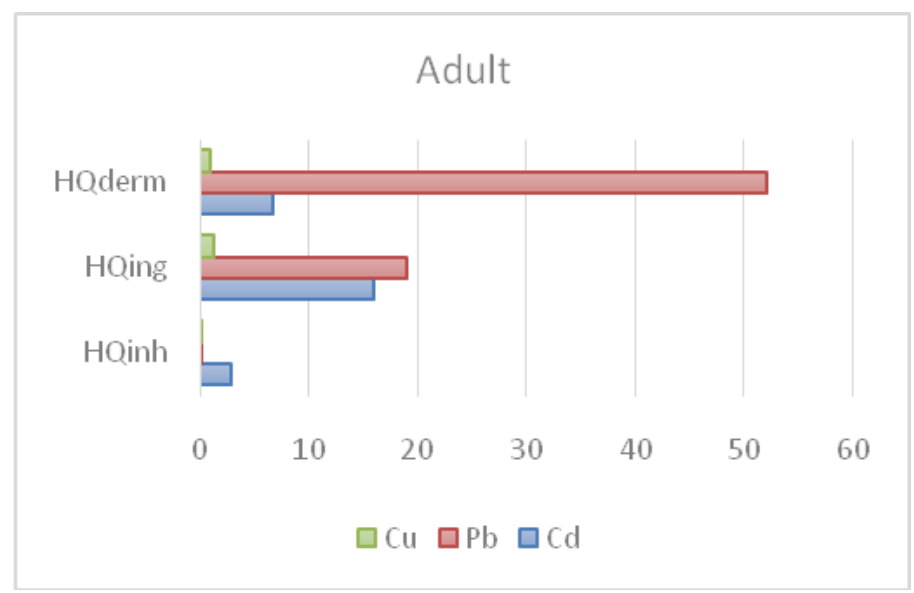

Figure 3

Adult Hazard Quotient (HQ's) for PRP G/Ruwa for all the pathways

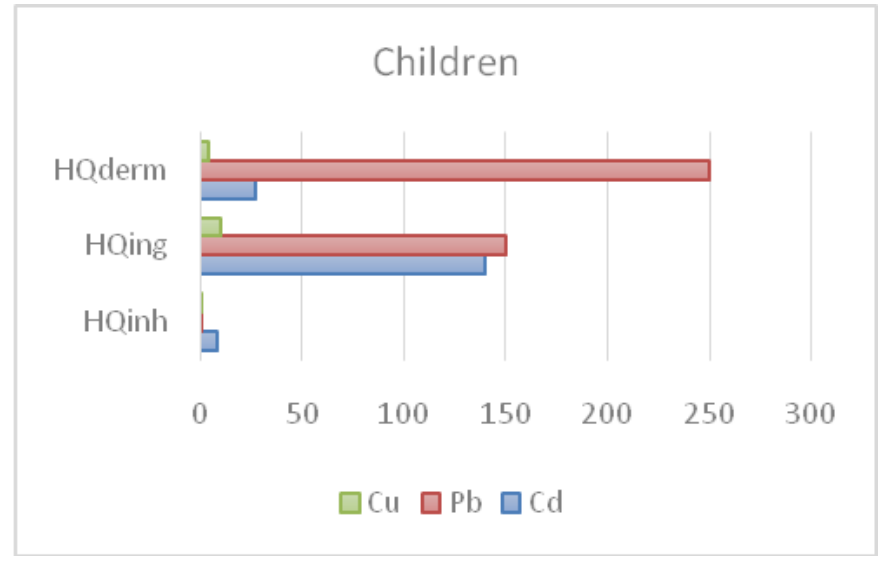

Figure 4

Page 14/16 


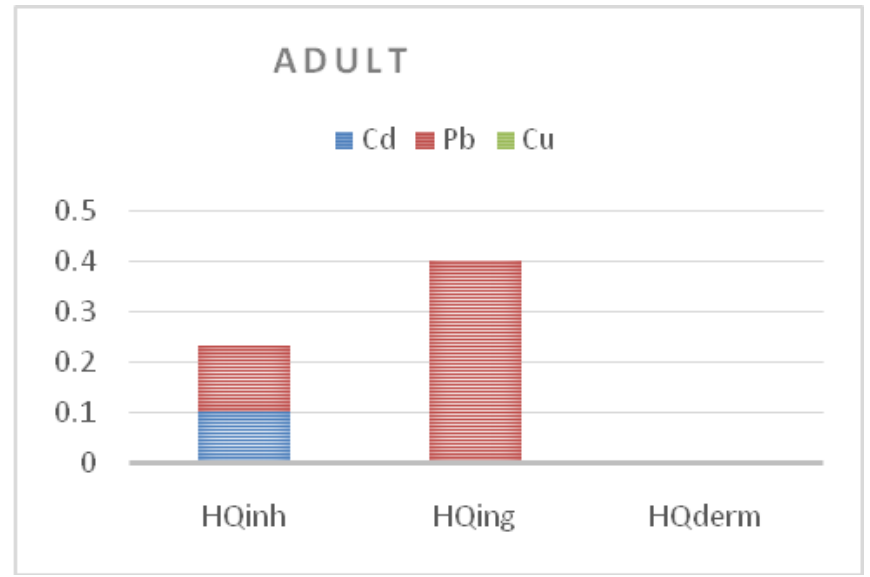

Figure 5

Adult Cancer Risk for K/Bulukiya treatment points for all the pathways

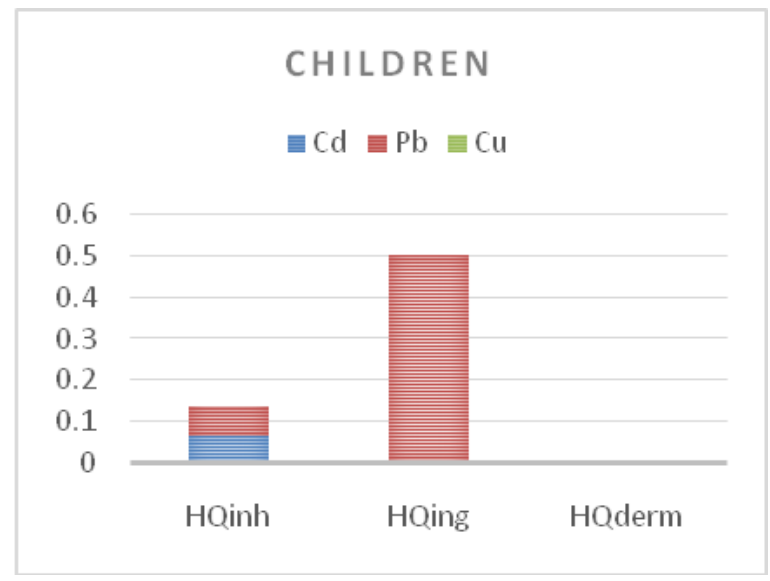

Figure 6

Children Cancer Risk for PRP G/Ruwa treatment points for all the pathways

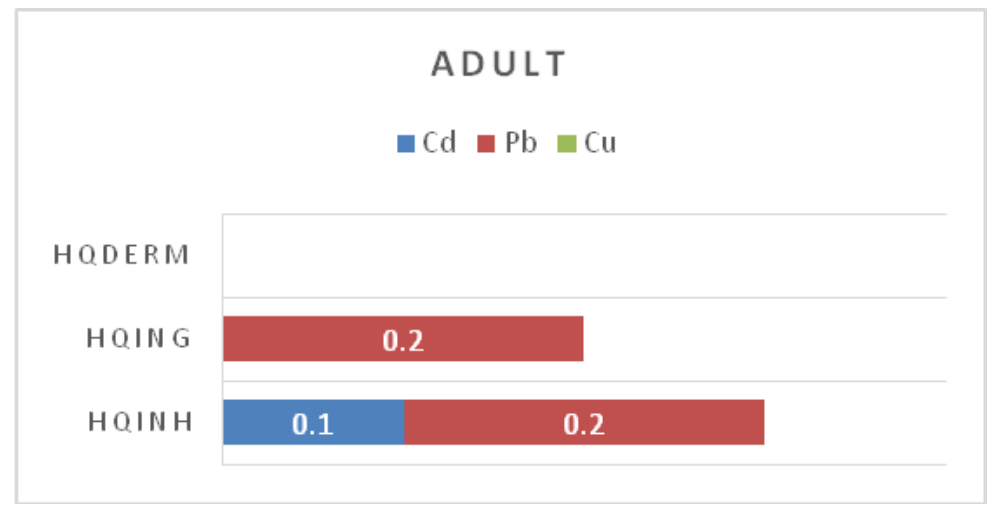

Figure 7

Adult Cancer Risk for PRP G/Ruwa treatment points for all the pathways 


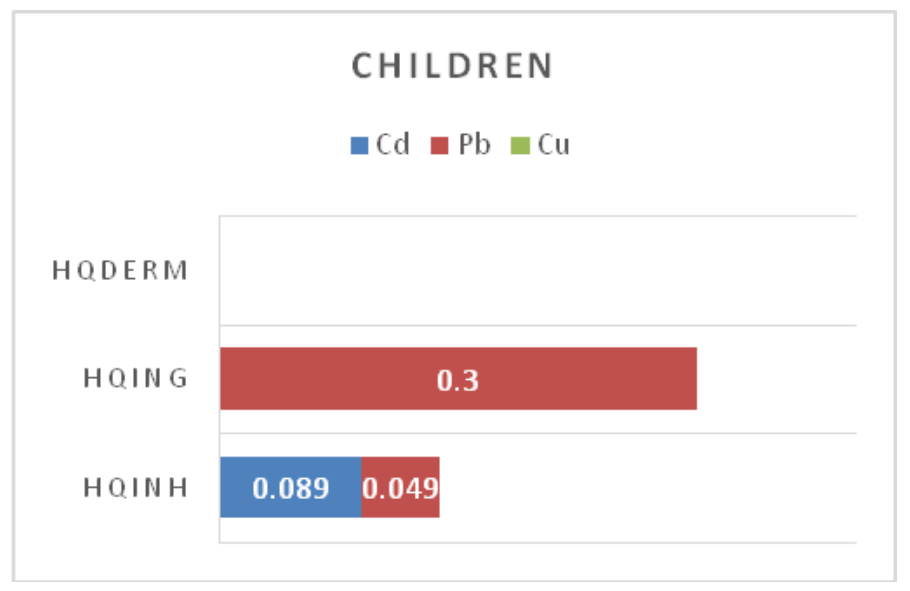

\section{Figure 8}

Children Cancer Risk for PRP G/Ruwa treatment points for all the pathways

\section{Supplementary Files}

This is a list of supplementary files associated with this preprint. Click to download.

- Plate1.jpeg 